School Leadership and Management 2002

Vol 37 (22), pp. 371-387

\title{
School-based induction tutors: a challenging role
}

\author{
Ruth Heilbronn, Cath Jones, Sara Bubb, and Michael Totterdell \\ Institute of Education, University of London
}

\begin{abstract}
Abstract

Since September 1999, all Newly Qualified Teachers (NQTS) in England who wish to teach in the maintained sector have to complete an induction period. In the light of the introduction of this statutory policy, this paper critically examines the key role of the school based induction tutor in managing the process. It draws upon an analysis of the government's induction circulars (DfEE/S 1999;2000;2001) and uses empirical data from a large, national DfES-funded project which evaluated the implementation of the policy. We argue that, for the majority of schools the work of the induction tutor within the whole school context, including management by the headteacher, is the major factor in the success of the policy. Further, we argue that there remain some tensions in the policy between the professional development and the assessment agenda.
\end{abstract}


School-based induction tutors: a challenging role

\section{Ruth Heilbronn, Cath Jones, Sara Bubb, and Michael Totterdell Institute of Education, University of London}

\section{Introduction}

This paper addresses an aspect of school management of induction, namely the role of the induction tutor. The induction tutor's role was one area of investigation in a wider, national research project carried out at the Institute of Education between October 2000 and December 2001. There were four overarching aims of the project. These were to assess:

1. The effectiveness of mechanisms for carrying out the induction of NQTs, including the cost effectiveness of its various different components.

2. The effectiveness of dissemination of information by DfES, TTA and Appropriate Bodies about the statutory arrangements.

3. The impact on the effectiveness of NQTs as a result of undergoing the induction year.

4. The impact on recruitment and retention of NQTs.

The four research aims were broken down into 40 research objectives. Case studies comprising semi-structured interviews, fieldnotes and school-produced documents and questionnaire surveys were carried out. An NQT, an induction tutor and the headteacher in 24 state-maintained primary and secondary schools were interviewed twice - near the beginning and end of an induction period - to gain some insight into changes in practice and perspective over time. Appropriate Bodies in which the school case studies were to be located were initially selected by geographical diversity, i.e. urban/rural and by region. Telephone interviews with representatives from 18 Appropriate Bodies, (17 LEAs and the Independent Schools Council Teacher Induction Panel - ISCTIP) were conducted. The LEAs were chosen to represent a wide range of size and type of local authorities nationally, avoiding those undergoing inspection. Nine were then identified for the case studies, of which one subsequently dropped out. The eight Appropriate Bodies were asked to identify one school which they deemed to offer 'best practice' in induction provision. The researchers selected a further two case study schools, ensuring that at least one primary and one secondary school were seen within each Appropriate Body, and that the sample contained a range of characteristics overall, e.g. small, foundation, single sex etc.

This data was complimented by a survey of 568 NQTs from the 1999-2000 and 2000-2001 induction cohorts, 238 induction tutors and 247 headteachers. The surveys were used to gather data from many individuals on the same topics and to enable patterns and trends to be identified. The design and sampling for the surveys aimed to maximise participation whilst giving economy of distribution. For the surveys of NQTs undergoing induction in 1999-2000 we selected potential participants by stratified random sampling, using the DfES database of teachers who had successfully completed their induction period the previous summer. The induction tutor and headteacher samples were also drawn from a DfES database and were random, except for ensuring geographical spread. We also conducted semi-structured telephone interviews with key personnel in supply teacher agencies to explore particular issues for NQTs on supply. The full report of this research has been published.(Totterdell et al. 2002)

The starting point for the evaluation were the intentions of the policy, as expressed in Circular 5/99: The Induction Period for Newly Qualified Teachers, and research findings which highlighted the weaknesses of the induction of newly qualified teachers (NQTs) before the statutory




regulations came into effect, in September 1999. These formed the basis against which empirical findings were compared and contrasted. Our overall approach was therefore to compare the 'intentions' of the policy with the 'outcomes' or actual practices of school, Appropriate Bodies and other bodies. The research objectives were carefully distributed between the case studies and the surveys, according to the most suitable respondent and the depth of answer required.

Table 1 shows the number of participants in the research. The 'target number' is that agreed between the researchers and the steering group. The 'total sample' is the number of questionnaires sent out, or requests by letter for individuals and schools to participate. The 'response rate' shows the percentage of the target and the actual number of individual respondents.

Table 1. Research methodology

\begin{tabular}{|c|c|c|c|c|c|}
\hline \multirow{2}{*}{$\begin{array}{l}\text { Research } \\
\text { Strategy } \\
\end{array}$} & \multirow{2}{*}{$\begin{array}{l}\text { Data Collection } \\
\text { Method }\end{array}$} & \multirow[t]{2}{*}{ Date } & \multicolumn{3}{|c|}{ Number of Participants } \\
\hline & & & $\begin{array}{l}\text { Target } \\
\text { no. }\end{array}$ & $\begin{array}{l}\text { Total } \\
\text { Sample i.e.. } \\
\text { number approached } \\
\end{array}$ & $\begin{array}{l}\text { Response rate } \\
\% \text { of target no. } \\
\& \text { actual number }\end{array}$ \\
\hline \multirow[t]{3}{*}{$\begin{array}{l}\text { Appropriate } \\
\text { Body case study }\end{array}$} & $\begin{array}{l}\text { Appropriate Body } \\
\text { telephone interview } \\
1\end{array}$ & Oct. '00 & 20 & 20 & $90 \%(18)$ \\
\hline & $\begin{array}{l}\text { Appropriate Body } \\
\text { telephone interview } \\
2\end{array}$ & Sept. '01 & 18 & 18 & $72 \%(13)$ \\
\hline & $\begin{array}{l}\text { Appropriate Body } \\
\text { documents }\end{array}$ & Oct'00 & $\mathrm{N} / \mathrm{A}$ & $\mathrm{N} / \mathrm{A}$ & N/A (10) \\
\hline $\begin{array}{l}\text { Appropriate } \\
\text { Body survey }\end{array}$ & $\begin{array}{l}\text { Appropriate Body } \\
\text { questionnaire }\end{array}$ & Nov. '00 & 150 & 154 & $62 \%(93)$ \\
\hline $\begin{array}{l}\text { Supply } \\
\text { agency }\end{array}$ & $\begin{array}{l}\text { Supply agency } \\
\text { telephone } \\
\text { interviews }\end{array}$ & Jun. '01 & 8 & 13 & $100 \%(8)$ \\
\hline \multirow[t]{3}{*}{$\begin{array}{l}\text { School case } \\
\text { study }\end{array}$} & $\begin{array}{l}\text { Headteacher, } \\
\text { Induction } \\
\text { Tutor and NQT } \\
\text { interview 1 }\end{array}$ & $\begin{array}{l}\text { Dec. '00 } \\
\text { Jan '01 }\end{array}$ & 72 & 78 & $92 \%(66)$ \\
\hline & $\begin{array}{l}\text { Headteacher, } \\
\text { Induction } \\
\text { Tutor and NQT } \\
\text { interview } 2\end{array}$ & $\begin{array}{l}\text { Apr. - } \\
\text { Jun. } \\
{ }^{\prime} 01\end{array}$ & 72 & 66 & $84 \%(59)$ \\
\hline & $\begin{array}{l}\text { Collection of } \\
\text { documents } \\
\text { from the } 24 \text { schools }\end{array}$ & $\begin{array}{l}\text { Jan. } 01 \\
\text { and } \\
\text { Apr. '01 }\end{array}$ & $\mathrm{N} / \mathrm{A}$ & $\mathrm{N} / \mathrm{A}$ & N/A (16) \\
\hline \multirow[t]{3}{*}{$\begin{array}{l}\text { School } \\
\text { survey } 1\end{array}$} & $\begin{array}{l}\text { State school head } \\
\text { teacher } \\
\text { questionnaire }\end{array}$ & Mar'01 & 250 & 650 & $99 \%(247)$ \\
\hline & $\begin{array}{l}\text { State school } \\
\text { induction } \\
\text { tutor questionnaire }\end{array}$ & Mar'01 & 250 & 650 & $89 \%(223)$ \\
\hline & Special school head & Mar '01 & 20 & 45 & $90 \%(18)$ \\
\hline
\end{tabular}




\begin{tabular}{|c|c|c|c|c|c|}
\hline & $\begin{array}{l}\text { teacher } \\
\text { questionnaire }\end{array}$ & & & & \\
\hline & $\begin{array}{l}\text { Special school } \\
\text { induction } \\
\text { tutor questionnaire }\end{array}$ & Mar ‘01 & 20 & 45 & $70 \%(14)$ \\
\hline & $\begin{array}{l}\text { Sixth form college } \\
\text { principal } \\
\text { questionnaire }\end{array}$ & Mar '01 & 20 & 45 & $80 \%(16)$ \\
\hline & $\begin{array}{l}\text { Sixth form college } \\
\text { induction tutor } \\
\text { questionnaire }\end{array}$ & Mar '01 & 20 & 45 & $90 \%(18)$ \\
\hline & $\begin{array}{l}\text { Independent school } \\
\text { principal } \\
\text { questionnaire }\end{array}$ & Mar '01 & 30 & 75 & $117 \%(36)$ \\
\hline & $\begin{array}{l}\text { Independent school } \\
\text { induction tutor } \\
\text { questionnaire }\end{array}$ & Mar ‘01 & 30 & 75 & $107 \%(32)$ \\
\hline \multirow[t]{2}{*}{$\begin{array}{l}\text { School } \\
\text { survey } 2\end{array}$} & $\begin{array}{l}\text { NQT questionnaire } \\
\text { 1: } \\
\text { 1999-2000 cohort }\end{array}$ & Dec '99 & 250 & 600 & $96 \%(240)$ \\
\hline & $\begin{array}{l}\text { NQT questionnaire } \\
2: \\
\text { 2000-2001 cohort }\end{array}$ & Jun ‘01 & $\begin{array}{l}250+30 \\
*\end{array}$ & 830 & $\begin{array}{l}121 \%+87 \% \\
(302+15+11)^{* *}\end{array}$ \\
\hline
\end{tabular}

$*=250$ people with QTS who were teaching and doing induction plus 30 not teaching or teaching but not doing induction. ${ }^{* *}=302$ teachers on induction plus 15 teaching but not doing induction plus 11 not in teaching.

\section{Introduction - the lead up to statutory induction}

Induction has a long history. Tickle (1994, p.12) and Simco (2000, p.7-10) report on three major attempts between 1925 and 1972 to move policy forward so that the first year of teaching had characteristics of both assessment and systematic professional development. In 1925, the then Board of Education, attempted to link initial training and induction. In 1944 the McNair Report established the principle of assessing and encouraged professional support and monitoring (McNair 1944). The James Report of 1972 sought to provide proper support and monitoring of new teachers' work with the assessment of their competence, in the expectation of a more equal balance between assessment and professional development (James 1972).

However, Simco (2000) points to a number of of the first year of teaching suggesting that classroom reality did not always reflect this policy framework. Many new teachers appeared to have inadequate information, were isolated and saw the first year of teaching as concerned only with assessment of their competence rather than any systematic professional development. This is echoed by Bolam et al. (Bolam 1995). The three HMI reports on induction spanning the 1980s and early 1990s come to similar conclusions. Although they indicate some improved practice the overall picture was disappointing. (DES 1982 )

In 1992 the probationary year was abolished. There was no longer to be an assessment of the first year of teaching nor a requirement on schools to provide induction. NQTs' experiences were even more varied between 1992-1999 (Bleach 1999, p.12). Some LEAs and schools supported and

$$
\frac{1}{\mathrm{k},},,, \mathrm{r}
$$


monitored NQTs well but others left them to sink or swim. Some LEAs provided extensive induction programmes and training for mentors, but many found these hard to maintain. As Bleach says, 'There was little more than the professional integrity of heads, teachers and advisers to sustain and encourage good practice' (Bleach 1999, p.2).

At the same time, however, evidence of some good practice was emerging, such as LEA portfolios to aid NQTs' professional development and observation formats using lists of teaching competencies. The teacher training reforms which involved more partnership between schools and training institutions enabled schools to feel more confident about supporting, monitoring and assessing beginning teachers. Many had become familiar with the competence-based assessment for qualified teacher status (Simco 2000, p.13). The introduction of the OFSTED inspection structure, though traumatic, meant that the quality of teaching and learning was discussed using common criteria. In particular it led to more focussed observations of teaching. Additionally, some LEAs worked with higher education institutions to accredit NQT and mentor training.

Nevertheless, the issue of addressing individual needs was not uniform throughout the country and 'the induction programmes and procedures do not always provide for a process of rigorous and systematic professional development' (Simco 1995, p.271). Thus, issues surrounding induction policy and practice have been stubbornly persistent over a very long period of time.

Overall, there was widespread consensus (e.g. Earley and Kinder 1994; HMI 1993; Mahony 1996; Simco 1995) that throughout the country:

- provision was highly variable

- there were no systematic links between induction and the early professional development of teachers

- the issue of individual needs was not uniformly addressed

The proposal to reintroduce statutory induction for NQTs to 'consolidate skills' learnt during initial teacher education was announced in the 1997 White Paper 'Excellence in Schools' (DfEE 1997). Induction was made statutory in England for all gaining qualified teacher status (QTS) after May 1999. By the start of and during our research project, which covered the academic years 1999-2001, some large and small-scale research on statutory induction had already been carried out. The most significant were Ofsted (2001) and FEFC (2001) on all elements of induction; NUT (2001) on pass, failure and retention of NQTs; Merry et al. (2000), a comparison of cohorts of NQTs

who had/had not done statutory induction, and McLeod (2000) on the use of the Career Entry Profile..

Our research report gives a full summary of the statutory regulations and previous research on their effectiveness and describes how our own research builds upon the above quoted studies. (Totterdell et alia 2002 pg. 11-17) It describes how we sought to provide current data on a national scale that covered all aspects of induction, both provision and impacts. Some significant questions which ran throughout the research and are reported in full in the report (ibid) are:

1. To what extent, if any, has statutory induction decreased the variability previously found in induction provision across and within LEAs and schools?

2. Are the intentions of the induction policy being realised on the ground within schools?

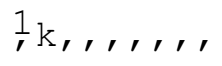


3. What factors can be identified as enhancing and inhibiting 'effective' induction?

This article will focus on the second of these questions and particularly the induction tutor's key role in delivering statutory induction. Statutory induction is the new teacher's first step into full participation in the professional role of the teacher. The support and development given at this point is therefore crucial for the new teacher's future career and the induction tutor is a formative and key influence on it. The statutory induction period provides an individualised programme of monitoring and support, to give opportunities for NQTs to develop their knowledge, skills and achievements in relation to specific induction standards. NQTs are required to have a timetable of $90 \%$ of normal average teaching time to allow their induction programme to take place. The programme is organised and by induction tutors working in the NQTs' schools and monitored by the headteacher. It must take account of the NQT's strengths and areas for development. These are set out in the Career Entry Profile which each NQT brings from initial teacher training to the first teaching post. At the end of the induction period the NQT must demonstrate achievement of the induction standards, which themselves build on the standards assessed at the end of initial teacher training, for the award of Qualified Teacher Status.(QTS).

Induction is intended to be 'a bridge from initial teacher training to effective professional practice' (DfEE 1999, para1), leading into the whole career of further pedagogical learning experiences. In the current English context these relate to Continuing Professional Development (CPD), and the statutory obligation on schools to assess their teachers annually, through Performance Management. There are standards to be met at various points of promotion during the stages of a teacher's career (DfES 2002). These are essentially measurable outcomes which have to be demonstrated to an assessor through paper-based evidence. Their introduction as competencies in initial teacher education in the early 1990s, (DFE \& Welsh Office and TTA 1998) and at induction level in 1999 (DfEE 1999 and DfEE 2000) has been much debated. (e.g. Whitty 1991; Hyland 1993; Lum 1999; Carr 1993a; 1993b)

The present government has stated that the new CPD strategy and the teachers' standards framework enable teachers to take charge of their own professional development:

'Every teacher now has the opportunity to discuss... their learning and development needs annually with their line manager and to set one or more development objectives... You may also want to reflect on your learning and development needs at other points in the year. In deciding your development priorities, you will probably want to draw ideas from a number of different sources."

(DfES 2002: Introduction)

It seems then that the government recognise that entering into a process of review and reflection is essential to successful learning, understanding the importance of encouraging learners to make explicit what they know and how that knowledge is added to and re-evaluated. This relates to earlier work outlined above on the need to provide a balance between professional development and competence. (Simco 1995).

Satisfaction with developmental opportunities not narrowly tied to performance outcomes is important to professionals, and as the General Teaching Council recognise 'a culture in which teachers are enabled to learn and grow professionally throughout their careers' $(2001, \mathrm{Pg}$. 1) is a desirable one in which to foster professional autonomy and satisfaction. A successful experience of induction should therefore lead to increased satisfaction with the professional development opportunities available and help to retain teachers. This is particularly relevant in the light of

$$
{ }_{1} \mathrm{k},,,,,
$$


current statistics about the high number of teachers who leave the profession in the first three years. (Horne 2001) The CPD Strategy also however situates professional development firmly within a 'Performance Review' framework.

Statutory induction provides new teachers with an important early professional development opportunity, whilst at the same time being very harsh on failure. The induction policy contains a strict failure rule, namely if an NQT fails to pass the induction period s/he will not be allowed to follow induction training a second time. Registration as a teacher with the General Teaching Council will be cancelled and s/he will not then be able to teach in a state school or a nonmaintained special school. Yet the induction policy recognises that teachers need time and opportunity for reflection and builds in good practice in this regard, in terms of specific periods for mentoring and half termly setting and reviewing objectives, which are separate from the termly assessment meetings. Les Tickle has pointed out, for example how the programme is based on the identification and review of professional development yet is focused primarily on the use of the Career Entry Profile and Induction Standards. 'It is assessment led, based on a regulated range of teaching behaviours, and specific definitions of teaching quality - and that presents a problem' (Tickle 2001, Pg. 53)

Clearly there are tensions inherent in a policy which ties assessment to standards and also advocates a process-based view of learning. Les Tickle, in the article quoted, argues that the induction standards dominate the whole process. In fact, most NQTs we interviewed in our research believed that their period of statutory induction training and support had provided them with professional development in the wider sense. They were able to reflect on their learning experiences beyond the language of the induction standards, and were clear that they had developed as teachers, not as a result of the assessment against the standards, but through the professional dialogue on practice, with an experienced mentor. We found strong evidence to show overwhelming agreement among headteachers and induction tutors that statutory induction is helping NQTs to be more effective teachers as defined in terms of the outcomes discourse of the induction standards. On both the developmental and the assessment agenda then the policy has made a contribution to the early professional development of new teachers. The structure of the programme has helped to provide a framework of entitlement for all NQTs, which has been beneficial to the vast majority of NQTs undergoing statutory induction. We also found strong evidence that induction tutors accepted the need for making standardised assessments, without losing their perspective on their dual role in professional development and assessment. One induction tutor for example said:

'On the whole it's a good programme. I think it's important to have this period of induction ...it's an important process which I think is well structured...it allows me to do continuous monitoring.'

So the interesting question remains as to how the two strands have been balanced. This is where the qualities, skills and experience of the induction tutors play a key role.

\section{The induction tutor's qualities, skills and experience}

To define the exact nature of the induction tutor role and responsibilities in statutory induction we need to go to the policy document, which states that they are members of staff chosen by the headteacher 'to provide day to day monitoring and support' for the NQT (DfEE 2000, para. 1). They are responsible for organising the induction programme, and supporting, monitoring and assessing the NQT. Before statutory induction, the role was taken by variously named staff. Their function in terms of the professional development of the new teacher bore many similarities to that of the

$$
\frac{1}{r} \mathrm{k},,,,,
$$


current role, with its statutory duties and responsibilities, with one important difference. They did not need to adhere to a nationally standardised assessment of the new teacher at the end of their probation or training and the new teacher was not therefore barred from the profession if they 'failed' to get through within a given time limit.

With their dual role of support and assessment induction tutors need to have specific personal qualities and professional skills, as well as the pedagogic knowledge and experience to effectively tutor their NQTs and manage the induction programme. The policy states that they should be:

'fully aware of the requirements of the induction period and should have the necessary skills, expertise and knowledge to work effectively..., be able to make rigorous and fair judgements about the NQT's performance in relation to the requirement for satisfactory completion of the induction period and to provide or coordinate guidance and effective support for the NQT's professional development' (DfEE 2000, par. 26).

These requirements demand a high level of pedagogical expertise, assessment acumen, communication and mentoring skills, professional judgement and the ability to relate to the widest educational context. Since we completed the research the TTA, working with a group of induction tutors, has published a list of qualities and professional skills and experience and these are wide ranging. (TTA 2001, Pg. 6)_Unsurprisingly then we found that they were predominantly senior teachers, deputy headteacher or assistant headteacher. Seven percent were headteachers, normally in very small schools. Although over half the induction tutors in our research had not been responsible for NQTs before statutory induction, a large number had been involved in initial teacher training. (in the state sector $64 \%$ in secondary and $48 \%$ in primary schools). This had provided them with a basis for work with NQTs as they were able to build on what they had learnt through the practice of mentoring and training, and the professional development they had received for this work from their partnership HEIs. (Heilbronn 1997)

We found that previous experience in induction was useful to induction tutors, but some failed to understand the scope and precise application of the standardised assessment and other new regulations. In its inspection of induction OFSTED also found that 'many schools were building on previous good practice in supporting NQTs or ITT trainees, adding that 'this sometimes meant that they did not see the need to provide training that was specifically focused on the induction standards.' (OFSTED 2001, para.37). This underlines again the difficulty in the dual nature of the role, both professional development mentor, and assessor of the induction standards, since this aspect of the job is specific to the statutory guidelines. A case study induction tutor illustrated the possibilities for tensions between the functions of support, monitoring and assessment:

'You have to set up a relationship with NQTs in which they feel that they can tell you what difficulties they're experiencing, but you must back that up with your own observation and you have to develop a relationship in which you are able to give praise but also constructive criticism. But you also have to be prepared, to go into the relationship with each NQT knowing that it's possible that this NQT will fail... So it's a delicate relationship.'

The induction activity which was rated most highly by all respondents was lesson observation, both of and by the NQT, provided it was accompanied by an articulation of the processes and practices observed, in conjunction with an experienced mentor, who might be the induction tutor or another member of staff. NQTs viewed this professional dialogue as essential, and emphasised the need for

$$
\frac{1}{\mathrm{k},},,,, \mathrm{r}
$$


the expertise of good mentors. This clearly points to the importance of NQTs reflecting both on their own practice and on that of experienced teachers, through informed, critical dialogue. This model of learning is far from the outcomes model which is present in the final assessment instrument of the policy. The way that NQTs have told us they learn best fits the Schon model of the reflective practitioner, who undertakes 'reflection on action' (Schon 1995) and relies on teachers evaluating their work within a learning cycle, involving the necessary review of practice, before learning can take place. Our research therefore endorsed the arguments about the developmental experiences most useful to new teachers put forward by Tickle, for example. (1994). Such an understanding looks at the development of teaching capacity in the wider context of 'education as a process of growth' (Dearden, 1972). It relates well to how the NQTs valued the individual setting of objectives which arose from formative lesson observation and the follow up in weekly or fortnightly mentoring sessions. This professional formation follows the Kolb learning cycle of experience of practice, evaluation and re-experience of learnt, evaluated understanding and knowledge. (Kolb, 1984). It appears in the in-service context in the methods advocated by Joyce and Showers (1995) to start with an input on theory, with exemplification/modelling, followed by practice with feedback and 'coaching' support.

Interestingly induction tutors also rated the two forms of lesson observation as the most cost effective induction activities. Seventy two percent of respondents described observing teachers in NQTs' own schools as the most cost effective. This was closely followed by NQTs being observed and $70 \%$ felt this was very cost effective.

Drawing on these observations and other evidence the induction tutor brings particular skills to the formative review. These skills are valuable in many other contexts within school and the mentor's role is a crucial one for the new teacher's professional development. Because of the rise of competency based assessment, mentors in previous studies have stressed that their most important tasks are related to matters such as classroom management and planning. However, they have also rated very highly the need to get teachers to evaluate their teaching. Other researchers have found that 'as a group mentors are clearly concerned to ensure that teachers develop traits which will be vital to them throughout their professional careers', which are not narrowly tied to the final assessment. (Wright N. \& Bottery M. 1997, pg. 244).

The successful induction tutors we interviewed in best practice schools were enthusiastic teachers and managers, committed to developing the next generation of teachers. They valued the opportunity afforded them to work with new teachers. One said: 'It's one of the parts of my job that I enjoy the most'. Another said :

'In the vast majority of cases, they're young people who are enthusiastic, enjoy their work, and you know I find it very refreshing and I learn from watching them. I think this is the thing that's perhaps surprising, an experienced teacher can go and watch an NQT and still pick up some tricks.'

An induction tutor with previous experience of mentoring NQTs in another school consciously sought to appoint an NQT 'to bring fresh blood' into the school' and reflected that preparing work for NQTs supported whole school development. For instance, in one school a teacher put together a training document for NQTs that was then disseminated to the whole staff.

Success requires empathy towards the new teacher. One pointed out how she needed

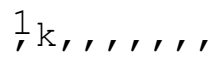


'to make an enormous conceptual leap, because we forget what it's like to be a new teacher, and most of us, certainly at my age, didn't have any kind of induction or support.'

With their dual role of assessor and support it is essential that induction tutors themselves have good training and support. Where schools have more than one NQT an induction manager is needed to coordinate provision and they then provide some of the training internally. This is the case for $76 \%$ of secondary respondents and $55 \%$ of primary. In sixth form colleges almost $2 / 3$ of respondents (11/18) have the role of induction coordinator. They help to iron out inconsistencies in provision and oversee quality. We found many such managers in place in the schools we visited. We will examine the sources of training and preparation for the role in the next section of the paper.

\section{Preparation and support in the role}

Induction tutors draw on a variety of sources of preparation for aspects of their role. As well as the immediate benefits for the NQTs, support and training in this role develops induction tutors' own wider professional competence. The TTA have commented for example that induction tutors gain experience and skills 'that are directly transferable to other management roles and responsibilities' and that their work gives them 'opportunities to reflect on approaches to achieving quality in teaching and learning' (TTA 2001 p.10) This backs up the findings of other researchers (e.g. Shaw, quoted in TTA 1992).

Induction tutors should therefore have access to high quality professional development. Overall, the majority of respondents felt confident that they had been well prepared and supported for carrying out their role. However, $8 \%$ were either not very or not at all confident about the preparation and support they had received. This rose to $12 \%$ in sixth form colleges and $15 \%$ in special schools, suggesting that more needs to be done for these induction tutors. OFSTED were particularly concerned about the preparation and support they received for assessment of NQTs. (OFSTED 2001c). However, those we interviewed were confident about their developmental support role and we agreed with the OFSTED findings that most key staff in schools 'had a very good understanding of the QTS and induction standards and had planned the induction programme to ensure that the NQTs achieved these.' (OFSTED 2001, para.34). It seems then that many induction tutors have managed to gain training, or to train themselves to become competent assessors. Given the seniority of their position in school, with its implication of good classroom practice and the opportunity and ability to have an overview of educational practices this is not surprising. However, support and training from the Appropriate Body should be a fundamental entitlement for the induction tutor.

On assessment we asked induction tutors to rate a whole range of various sources of preparation and support on a four point scale, in terms of how useful they were in gaining the knowledge and skills they needed for assessing NQTs. All the sources we quoted were found to be useful by the majority of induction tutors and it is particularly interesting that the most frequently mentioned resource was the respondents' own schools. The fact that a slightly higher percentage of primary than secondary induction tutors found informal meetings with other teachers/headteachers very useful $(27 \%)$ compared to secondary $(15 \%)$, probably reflects the two sectors relative size and organisational structures.

The LEA was a well used source of support and training for induction tutors. Seventy two percent of state school induction tutors said that they had received support and training for their role (79\%

$$
\frac{1}{k} \mathrm{k}, r, r,
$$


in special schools) from their LEA. Two out of every three induction tutors surveyed reported that the quality and appropriateness of Appropriate Bodies' support was useful. induction tutors particularly valued initial meetings at which the statutory requirements were outlined and expectations for the period were made clear. Moderation workshops and opportunities to share good practice on specific, semi-structured topics were also highly favoured. Sessions where teachers were informed about the 'basics' of an aspect of induction and then had opportunities to discuss their application in their own school contexts were highly praised induction tutors appreciated LEA and ISCTIP staff $r e$-interpreting and mediating the TTA and DfES documents with a view to practical implementation. Poorly presented information was criticised.

Networking is very useful for induction tutors, but unfortunately they often found great difficulty in being released from school. Opportunities for induction tutors from different schools to meet together were organised by $37 \%$ of the Appropriate Bodies surveyed. Appropriate Bodies either invited induction tutors to meetings or compiled and circulated contact details of local induction tutors. Some Appropriate Bodies distributed such lists only on request and many induction tutors wanted more such opportunities or forums where their own individual agendas could be met.

Appropriate Bodies experimented with a range of timing, i.e. during the day, twilight or evening sessions. However, it was difficult for induction tutors to take time away from other duties, and this may be dependent on senior staff did not valuing the potential of these meetings. Again there is a role to play in disseminating to senior management the advantages of spreading the understanding of good mentoring principles related to support and assessment in statutory induction, to the wider school community.

When this dissemination is effective and the whole staff have an understanding of the process and practices of induction in its wider as well as its statutory sense, the school as a whole benefits greatly. It is clear from our research that the schools with successful induction practice had a shared understanding and ethos of a learning environment for all staff and pupils. Where schools were supportive, NQTs recognised the input of a variety of staff, for example one secondary NQT talked about receiving 'invaluable support' from heads of year over behaviour issues. A primary NQT said 'the whole staff' helped her. Several NQTs explained how the staff as a whole, together with good LEA support, can make for a positive induction experience.

\section{Time for the role:}

The main issue for schools from the perspective of the induction tutor is finding the time to fulfil the role. The majority of induction tutors in all schools, in both years covered by our survey, were responsible for a single NQT, but some had considerably more. In the state sector approximately one fifth of the sample had five NQTs or more, in both of the years in question. There were differences between secondary and primary schools in this regard. Secondary school induction tutors were usually responsible for more NQTs than primary induction tutors, in both years covered by the survey. The majority of primary induction tutors had only one NQT. Some secondary school induction tutors had up to 16 NQTs, while a few primary induction tutors had up to 5 in 1999-2000 and 7 in 2000-2001.

One secondary headteacher spoke of workload difficulties with three NQTs in one department:

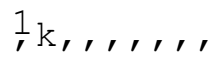


'They each have a separate mentor, which has not been easy... You need first of all to pick suitable people who've got suitable experience and are good at that role and secondly you are actually asking them to do something completely unpaid... it is quite a demand.'

He cited the case of a colleague who had agreed to be an induction tutor based on her experience prior to statutory induction. However, when she realised how much work was involved, she was unhappy about the role. So the headteacher arranged for the role to be shared with the head of faculty.

If an NQT needs extra support the workload implications are even greater. One primary induction tutor had an NQT who had failed his first assessment in another school. The induction tutor then worked closely with the NQT, setting monthly objectives:

'My role is very much one of supporting but also it's especially important in this situation that I've had to set very close targets to ensure that the NQT does achieve the standards required of him ... It's added to the strain of everything else I have to do in my role.'

There are workload implications for induction tutors with more than one NQT who also have trainees on initial teacher education (ITE) courses. On case study school had 10 NQTs and 3 ITE students being managed by the same induction manager, and others had high numbers to cater for. The 'paperwork' relating to the recording of the reviews and the assessments was seen as onerous and we received criticism from induction tutors over the level and nature of their accountability and the amount of evidence they needed to record.

We found much evidence in our case study schools to show that many staff involved in induction are dedicated and devote much of their energies to developing and retaining staff, often without being given time or financial reward. Some induction tutors and headteachers suggested accrediting the work involved, which would go some way to acknowledging the amount of time, effort and good will involved in doing the job well. As Lewis and Varley have said:

"It would seem to be an oversight that while the NQT was entitled to a reduced timetable there was no commensurate provision for the induction tutor to carry out their role." (Lewis and Varley 2000, p.10)

OFSTED found that almost all school staff supporting NQTs did so in their existing non-contact time or after school. Bubb also found that induction tutors thought they needed much more dedicated time to do the job (Bubb 2000b, p.4). Our research discovered that

- 69 per cent of induction tutors had no specific release time for carrying out their role

- the most common amount of release time allocated was between half an hour to an hour per week

- the number of hours spent on the induction of NQTs was much greater than classroom release time received

There is a consensus (Earley and Kinder 1994; Maynard 1995; Furlong 1995; Sixsmith 1999; Simco 1999; Heilbronn and Jones 1997) that the role of the induction tutor is central, but very demanding, requiring a great deal of both time and training, and that it needs to be given sufficient status and

$$
\frac{1}{\mathrm{k}},,,,, \mathrm{r}
$$


importance in schools. The NUT recommends that induction tutors should be allowed at least a half day release from teaching duties every alternate week to fulfil their role (NUT 2000, p. 2). As a result of our research we recommended to the DfES that there should be dedicated, regular, funded time for induction tutors. We found only one LEA which gave any earmarked funding for the induction tutor role. The sum dedicated was $£ 250$ for a year and although appreciated only paid for about one and a third days out of the classroom. Many headteachers made the point that the funding ( $£ 1000$ per term per NQT from April 2001) did cover the NQTs' release time and some of their training, but did not cover the induction tutor's time.

\section{Conclusion:}

Despite the time constraints on their work and other resourcing implications, many induction tutors we spoke to enjoyed the role. Some said, 'its one of the parts of my job that I enjoy the most'. It is certainly a vital role in the induction process. Most induction tutors find the role rewarding, though one induction tutor pointed out that she needed, 'to make an enormous conceptual leap, because we forget what it's like to be a new teacher, and most of us, certainly at my age, didn't have any kind of induction or support.' Many induction tutors valued working with NQTs, for the innovations which new teachers can bring and NQTs are often seen as a positive asset to the school. One induction tutor with previous experience of mentoring NQTs in another school consciously sought to appoint an NQT 'to bring fresh blood' into the school' and reflected that preparing work for NQTs supported whole school development. For instance, in one school a teacher put together a training document for NQTs that was then disseminated to the whole staff.

On the whole, induction tutors considered that the procedures for statutory induction were an improvement on past arrangements, being more formal and well structured, allowing for continuous monitoring.

However, there were a number of people who disliked elements of statutory induction such as the tension between supporting on the one hand and monitoring and assessing on the other.

Accountability made them anxious about paper work and the role took a great deal of time but had low status. They were concerned that the consequences of failure were too great.

There is undoubtedly a tension in having to implement both a process-based support methodology and what appears to be an outcomes based assessment requirement, expressed in terms of induction standards. The need for accountability and the 'once and for all', pass or fail aspect of the programme seems at odds with the professional development approach, which underpins the process of review and objective setting.

For NQTs to achieve the induction standards they need to be part of an ongoing professional dialogue with many staff, but particularly their induction tutor. The success of the policy, which was evidenced in the research, was due largely to the skills, knowledge and understanding of the majority of induction tutors, when they worked in a whole school setting which was conducive to learning, and where all staff were involved. We found many examples of highly skilled tutors, able to relate the particular context, performance and pedagogical developmental stage of the NQT to the wider professional context, and their ability to act both as mentor in the widest sense and critical assessor at the end of the programme. This role should be rewarded with dedicated professional time, and adequately resourced.

$$
\frac{1}{1} \mathrm{k},,,,,,
$$


Moreover the whole school culture in which the induction tutor, as a senior teacher, is embedded, has a great impact on the success of induction for NQTs. We found that schools with a 'learning culture', in which induction was seen as an integral part of an active and thriving professional development culture, enabled induction tutors to work the most effectively. Some headteachers in these schools found ingenious solutions to resourcing the role and prioritised it in their budgets. These headteachers saw its impact in terms of training and retention, and they valued highly the rigour and support which the training offered to its newly qualified teachers. adequately resourced. Finally, we found that since the introduction of the statutory induction policy in September 1999, the quality of provision for newly qualified teachers has improved. There is overwhelming agreement among headteachers and induction tutors that statutory induction is helping NQTs to be more effective teachers. 
References:

Bubb, S., Heilbronn R., Totterdell, M., Jones C and Bailey, M.(2002) Improving Induction:

Research Based Best Practice in Schools. London: Routledge Falmer

Calderhead J. and Lambert J.(1992) The Induction of Newly Appointed Teachers. London: GTC

Carr, D. (1993a) Guidelines for Teacher Training: The Competency Model, Scottish Educational Review 25, 1: pp.17-25.

Carr, D. (1993b) Questions of Competence, British Journal of Educational Studies 41: pp. 253 271.

Carre, C. (1993) 'The First Year of Teaching' in Bennett, N. and Carre, C. Learning to Teach. London, Routledge.

Dearden, R.F. (1972) Education as a Process of Growth, In Education and the Development of Reason, edited by Dearden and Hirst. London: Routledge \& Kegan Paul.

DES (1982) The New Teacher in School, London: HMSO.

DFE \& Welsh Office (1992) Initial Teacher Training (Secondary Phase). Circular 9/92. London: HMSO

DfEE (1997) Excellence in Schools, London: DfEE.

DfEE (1998a) Induction for New Teachers - a consultation document. London: DfEE: 26.

DfEE (1998b) Reducing the Bureaucratic Burden. London: DfEE.

DfEE (1998c) Teaching: High Status High Standards. Circular 4/98. London: DfEE.

DfEE (1999) The Induction Period for Newly Qualified Teachers. Circular 5/99. London: DfEE

DfEE (2000) The Induction Period for Newly Qualified Teachers. Circular 90/2000. London:

DfEE.

DfEE. (2001) Good Value CPD. Ref. 0059/2001. London: DfEE

DfES. (2001) Guidance on Producing a Professional Development Record. 0649/2001. London: DfES

DfES (2002) Http://www.teachernet.gov.uk/Standards_Framework/Standard-Index.Cfm). London DfES

Earley, P. and Kinder, K. (1994) Initiation Rights - effective induction practices for new teachers, Slough: NFER.

FEFC (2001) The Induction of Newly Qualified Teachers in Sixth Form Colleges. Darlington: DfEE.

Furlong J and Maynard T. (1995) Mentoring Student Teachers: The Growth of Professional

Knowledge. London \& New York: Routledge.

General Teaching Council (2001) Draft Professional Learning Framework. London: GTC

Heilbronn R, Jones C. (1997) New Teachers in an Urban Comprehensive. Stoke on Trent: Trentham Books

Horne, M. (2001) 'Shortage could last forever', Times Educational Supplement, News and Opinion, (31.08.01) London: TES

Hyland, T. (1993) Competence, Knowledge and Education, Journal of Philosophy of Education 27, no. 1 pp. 57-68.

Joyce B, \& Showers, B. (1995) Student Achievement Through Staff Development. New York:

Longman.

Kolb, D. (1984) Experiential Learning : Experience as the Source of Learning and Development.

Englewood Cliffs, N.J. and London: Prentice-Hall

Lewis, P. and Varley, S. (2000) 'Monitoring the Induction Experience of Newly Qualified Teachers', paper presented at British Educational Research Association conference, Cardiff, September 2000 .




Lum, G. (1999) Where's the Competence in Competence-Based Education and Training?, Journal of Philosophy of Education 33, no. 3, pp. 403-18.

McLeod, C. (2000) 'The Career Entry Profile as an Induction Tool', Professional Development Today, Summer 2000, pp.39-48.

McNair, A. (1944) The McNair Report: Teachers and Youth Leaders, London: HMSO.

Merry, R., Moyles, J., Chapman, L., Hislam, J., Kitson, N., Hunter-Carsch, M. and Suschitzky, W. (2000) 'Entering the Lion's Den! Experiences of Entrants in the First Year of Primary Teaching', paper presented at British Educational Research Association conference, Cardiff, September 2000.

NFER (National Foundation for Educational Research (2000) The LEA contribution to school improvement - a role worth fighting for, London: Local Government Association. URL: www.lga.gov.uk/lga/education/ [Accessed 20/8/01].

NUT (National Union of Teachers) (2000a) Short-changing the teaching profession? The report of a survey of central government and LEA funding of induction for newly qualified teachers in England during 1999-2000. London: NUT.

NUT (National Union of Teachers) (2000b) A Helping Hand - the role of the induction tutors. London: NUT.

NUT (National Union of Teachers) (2001) Crossing the Winning Line or Falling at the First Hurdle? London: NUT.

OFSTED (1999) Handbook for Inspecting Primary and Nursery Schools. London, The Stationery Office.

OFSTED (2001a) The Annual Report of Her Majesty's Chief Inspector of Schools, London: The Stationery Office.

OFSTED (2001b) Inspection of LEAs: grade criteria for inspection judgements, London: OFSTED.

OFSTED (2001c) The Induction of Newly Qualified Teachers, London: OFSTED.

Schon, D. (1995) The Reflective Practitioner : How Professionals Think in Action. Aldershot: Arena Sidgwick, S. (1996) 'Government Policy and the Induction of New Teachers', in R. McBride. Teacher Education Policy: Some issues arising from research and practice, London: Falmer Press, pp. 97-112.

Simco, N. (1995) 'Professional Profiling and Development in the Induction Year', British Journal of In-Service Education, 19(1) pp.3-4.

Simco, N. (2000) Succeeding in the Induction Year, Exeter: Learning Matters.

Stevenson, and Palmer (1994). Learning Principles, Processes and Practices. London: Cassell

Teacher Training Agency (1998) National Standards for Qualified Teacher Status. Requirements as set out in DfEE Circular 10/97. London: TTA

Teacher Training Agency (2001) The Role of Induction Tutor: Principals and Guidance. London: TTA

Tickle, L. (1994) The Induction of New Teachers; Reflective Professional Practice. London: Cassell

Tickle, L (2001) Professional Qualities and Teacher Induction, Journal of In-Service Education 27,1: pp. 51-64.

Tickle, L. (2000a) Teacher Induction: The way ahead. Buckingham: OUP.

Tickle, L. (2000b) 'Teacher Probation Resurrected: England 1999-2000', Journal of Education Policy, 15(6), pp.701-713.

TTA (Teacher Training Agency) (1998) Interim Findings on the Monitoring and Support Activities for Newly Qualified Teachers in the Induction Credit Feasibility Study. London: TTA.

Turner, M. (1994) 'The management of the induction of newly qualified teachers in primary schools', Journal of Education for Teaching 20(3), pp.229-236. 
Totterdell, M., Heilbronn R., Bubb S. and Jones C. (2002) Evaluation of the Effectiveness of Statutory Arrangements for the Induction of Newly Qualified Teachers. (Research Report 338)). London: DfES

Whitty, G \& Willmott. (1991) Competence-Based Teacher Education: Approaches and Issues, Cambridge Journal of Education 21, 3

Williams, A. and Prestage. S. (2000) Still in at the Deep End? Developing Strategies for the Induction of New Teachers London, Association of Teachers and Lecturers

Wright N. \& Bottery M. (1997) Perceptions of Professionalism by the Mentors of Student Teachers. Journal of Education for Teaching 23, 3, pp.235-51. 